
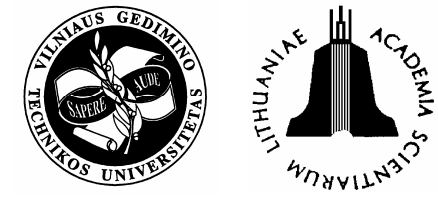

\title{
ON MODELLING HEAT AND MOISTURE TRANSFER IN SANDWICH WALL AND SLAB STRUCTURES
}

\author{
Vadim Nikitin $^{1}$, Andrzej Lapko ${ }^{2}$ \\ ${ }^{1,2}$ Bialystok Technical University, ul. Wiejska 45E, 15-351 Bialystok, Poland. \\ ${ }^{2}$ E-mail: lapko@pb.bialystok.pl \\ Received 21 Nov 2005; accepted 28 Mar 2006
}

\begin{abstract}
In real wall or slab structures made of capillary-porous materials (such as masonry or concrete) exposed to ambient air, the unsteady processes of heat transfer and moisture migration as reciprocal phenomena are observed. Basing on the Fourier general differential equations and using the assumptions of the elementary heat balance method, the problem of heat and moisture transfer has been studied in multi-layer wall structures, such as sandwich panels. As a result the general equations were proposed and transformed into formulas useful in the FDM approach (Finite Difference Method). On this basis a computer program was written to analyse the phenomena mentioned above. Some computational tests for a concrete sandwich panel wall with insulation made of foamed polyurethane were presented and discussed to illustrate a possible application of this approach. The paper shows that the improvement of computational accuracy of modelling the thermal engineering problems requires an assumption of real parameters which characterise capillary-porous structural materials and result from moisture transfer.
\end{abstract}

Keywords: heat transfer, moisture migration, sandwich walls, numerical analysis, durability.

\section{Introduction}

To reduce heat losses through multi-layer walls or slab structures erected in buildings, the designer can recently apply a large variety of different highly effective insulating materials. Selecting the most effective solution of the sandwich structure, various factors that may affect the efficiency of heat insulation in the partition should be taken into account The knowledge of real characteristics of complex unsteady heat transfer and moisture migration processes in the capillary-porous materials is very important. The solutions can be found analytically applying complex mathematical models basing on known mass and energy transfer equations, [eg Fokin (1973), Bear and Bachmat (1984)]. The problem becomes more complex in biochemical porous materials [Usowicz (2002), Vozarowa (2005)].

In practice, simulation methods are developed, using different approaches like Finite Element Method described, eg by Zienkiewicz (1991), Lewis and Schrefler (1998), Finite Difference Method presented eg by Gawin (2000), Kunzel and Kiessl (1997), or by the use of Artificial Network Method, eg by Gawin and Lefik (2000). For heat and moisture transfer simulation, an estimation of real material characteristic is needed, eg Wyrwal and Swirska (1998).

In this paper some results of numerical simulation of coupled hygro-thermal phenomena in multi-layer members are presented to continue the discussion from our earlier papers: Afonin and Nikitin (2002), (2003) and Lapko et al (2001), (2002), to estimate the effects of functional parameters depending on higro-thermal characteristic of the building material considered.

\section{Computational assumptions}

Coupled unsteady processes of heat transfer and moisture migration in capillary porous materials of building partitions may be described by Fourier differential equation which, in general, represents the principle of unsteady field for any potential transfer. Taking into account the cylindrical co-ordinates, we can analyse not only cylindrical walls but also plane wall structures, assuming sufficiently large radius of the multi-layer structure.

Differential time depending equations of heat transfer considered in cylindrical co-ordinates can be written as follows

$$
c \rho \frac{\partial t}{\partial \tau}=\lambda\left(\frac{\partial^{2} t}{\partial r^{2}}+\frac{1}{r} \frac{\partial t}{\partial r}\right),
$$

where:

$t$ - temperature distribution against time $\tau ; r$ - the radius of the wall or slab structure; $\lambda$ - thermal conductivity; $c$ - specific heat capacity; $\rho$ - density of the building material considered.

The diffusive migration of moisture (in the form of vapour) in pores and capillaries of the considered building material, using notation given in PN-EN-ISO (1999) can be expressed by an analogous equation 


$$
\frac{\partial p_{v}}{\partial \tau}=\frac{\delta_{p} p_{v, s a t}}{\xi}\left(\frac{\partial^{2} p_{v}}{\partial r^{2}}+\frac{1}{r} \frac{\partial p_{v}}{\partial r}\right)
$$

where:

$p_{V}$ - partial vapour pressure $[\mathrm{Pa}] ; p_{v, \text { sat }}-$ partial vapour pressure related to the saturation state $[\mathrm{Pa}] ; \delta_{p}-$ coefficient of vapour transmission $[\mathrm{g} /(\mathrm{m} \cdot \mathrm{h} \cdot \mathrm{Pa})]$ and $\xi$ - differential humidity capacitance $\left[\mathrm{kg} / \mathrm{m}^{3}\right]$ given as

$$
\xi=\frac{d w}{d \phi},
$$

where:

$w$ - mass contents of moisture at the unit of volume; $\phi$ - relative humidity of material.

The migration of moisture in the liquid phase for saturated humidity condition of material can be written as

$$
\frac{\partial w}{\partial \tau}=D_{w}\left(\frac{\partial^{2} w}{\partial r^{2}}+\frac{1}{r} \frac{\partial w}{\partial r}\right),
$$

where $D_{w}$ - coefficient of moisture transmission $\left[\mathrm{m}^{2} / \mathrm{s}\right]$.

The solution of the system of equations (1), (2), (3) using analytical methods is very complex, therefore, for practical computations, the application of approximate methods is usually used. For instance, the procedure based on the Finite Difference Method (FDM) could be applied. To solve this problem, a well-known method of elementary heat balances proposed, eg by Micheyev and Micheyeva (1973) has been used here.

The computations were carried out in cylindrical co-ordinates for a thin walled cylindrical partition consisting of elementary layers having the thickness $\Delta r$ and the unitary height $h=1$. The temperature and humidity for each elementary cylindrical layer were assumed to be constant and equal to temperature and humidity on midsurface of the wall as presented in Fig 1.

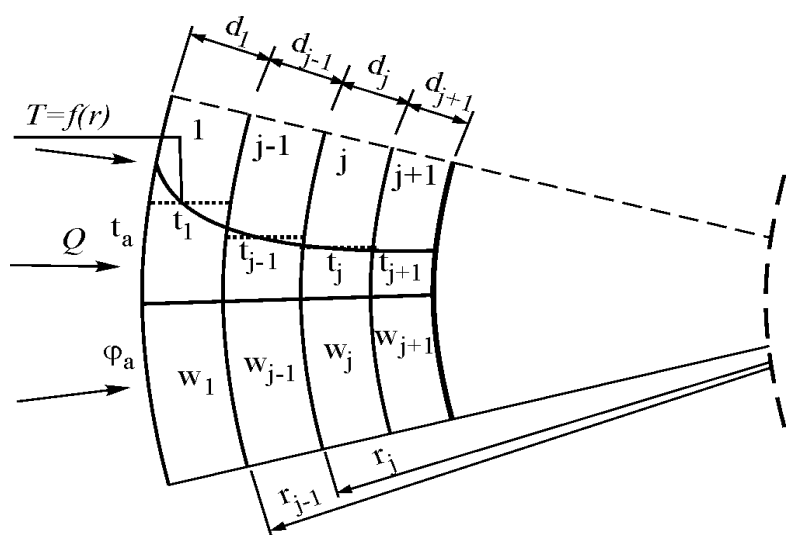

Fig 1. Assumptions for the analysis of unsteady axisymmetric heat flow coupled with moisture migration in cylindrical co-ordinates according to Lapko et al. (2001)

The equations of elementary balances in the considered case were defined for three elementary cases, as presented in Lapko et al. (2001):

1) transfer between surrounding air and the outside elementary layer of structure,
2) transfer between layers made of homogenous materials,

3) transfer across the contact of layers made of different capillary-porous materials (such as concrete wall with thermal insulation).

As an example, let us write the equation of elementary heat balance for the external layer (1-st elementary element in the structure) having the dimensions given by external $r_{1}$ and internal $r_{2}$ radiuses $\left(r_{1}-r_{2}=\Delta r / 2\right)$

$$
Q_{0}-Q_{2}=\Delta U_{1},
$$

where $Q_{0}$ and $Q_{2}$ - the quantities of heat flowing into the external 1-st element with the air flow and heat from the 2-nd adjacent element during the small finite time interval $\Delta \tau$ and $\Delta U_{1}$ is the increase (or decrease) of heat content in the 1-st element in the time interval $\Delta \tau$.

According to Newton's law, the heat amount $Q_{0}$ coming into the external elementary layer with the air flux during the time interval $\Delta \tau$ can be expressed

$$
Q_{0}=2 \pi r_{1} \alpha\left(t_{a}-t_{1}\right) \Delta \tau,
$$

where:

$t_{a}$ and $t_{1}$ - temperature for air and the 1-st element in the initial moment of time, respectively; $\alpha$ - the coefficient of heat transfer for the convection between surrounding air and surface of the 1-st layer, $\left[\mathrm{W} /\left(\mathrm{m}^{2} \cdot{ }^{0} \mathrm{C}\right)\right]$.

The amount of heat coming into the 1-st layer from the 2-nd adjacent layer with the external radius $r_{2}$ and internal radius $r_{3}\left(r_{2}-r_{3}=\Delta r\right)$ in the time interval $\Delta \tau$ on the basis of known Fourier law is equal to

$$
Q_{2}=2 \pi r_{2} \lambda\left(t_{2}-t_{1}\right) \Delta \tau / \Delta r
$$

where $t_{1}$ and $t_{2}$ - temperature for the 1-st and the 2-nd layer in the initial moment of time.

The increase of quantity of heat in the outer (the 1-st) elementary layer during time $\Delta \tau$ equals to

$$
\Delta U_{1}=c \rho \pi\left(r_{1}^{2}-r_{2}^{2}\right)\left(t_{1}^{*}-t_{1}\right),
$$

where $t_{1}^{*}$ - the temperature of outer layer at the end of time interval $\Delta \tau$.

Analogous with the equations of elementary heat balances were expressed here for all considered cases. At the contact of two different materials the assumption about continuity of temperature, vapour pressures and flow of moistures in liquid phase should be considered. The condensed moisture appearing on the contact between two layers (consisting of different materials) was distributed at two half layers $(\Delta r / 2)$ proportionally to the velocity of capillary suction of water by the given material. The formulas used in computation procedures elaborated for estimating of thermal and moisture fields are taken from the paper presented by Nikitin et al (2001).

On the basis of assumptions presented above a computer program was elaborated for the needs of numerical simulation of coupled problems of heat and moisture migration in different building structures consisting of capillary-porous materials. The computer program requires such input data: heat and moisture transmission coefficients, density and specific heat of material, num- 
ber of elementary layers into which the structure is subdivided for heat and moisture calculation purposes, density, thickness and initial temperature in each considered layer of the sandwich structure.

\section{Numerical modelling the temperature and humid- ity condition in sandwich partition}

An external concrete wall of the thickness $150 \mathrm{~mm}$ (density $2300 \mathrm{~kg} / \mathrm{m}^{3}$ ) with athermal insulation made of foamed polyurethane (density $50 \mathrm{~kg} / \mathrm{m}^{3}$ ) and the thickness of $100 \mathrm{~mm}$ was adopted for calculation (Fig 2). The outer cladding of such partition covering the thermal insulation is $15 \mathrm{~mm}$ thick plaster work having the properties of cement-lime mortar of the density $1800 \mathrm{~kg} / \mathrm{m}^{3}$.

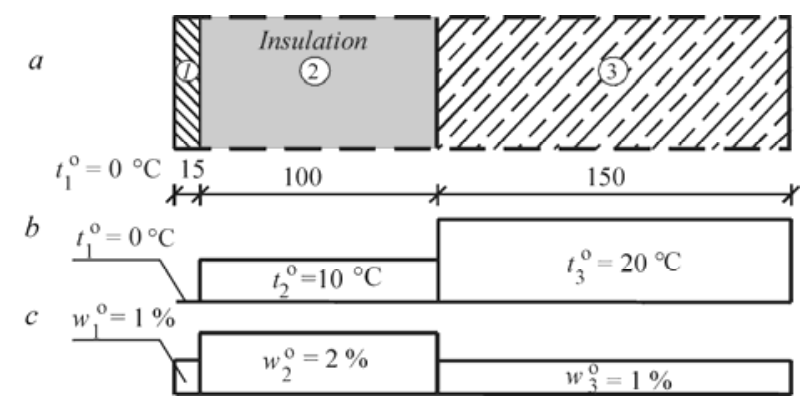

Fig 2. Structure of the analysed multi-layer wall with a thermal insulation (a), mean temperature distribution (b) and mean moisture content in the layers (c)

In order to conduct the analysis, it is necessary to define the parameters characterising the surrounding air condition, as well to predict the respective thermophysical properties and material parameters.

To analyse the most adequate temperature distribution and moisture field in such multi-layer structures meteorological data related to one of the winter months in Poland have been used. In Polish climate conditions an average December air temperature equals to $-4{ }^{\circ} \mathrm{C}$, whereas the relative air humidity $-\phi_{\mathrm{e}} \approx 95 \%$. Such data were registered eg in North-East region of Poland in Dec 2001 and Jan 2002, when the air humidity during the whole the month did not fall below $90 \%$ and, in the course of few days reached almost $100 \%$.

The indoor temperature was assumed to be equal to $20{ }^{\circ} \mathrm{C}$ and indoor air humidity equal to $\phi_{i}=60 \%$. The other parameters needed for the computational purposes were established from literature data, after Fokin (1973) and from Polish Standard PN-EN-ISO 6946 (1999).

The initial conditions of temperature and humidity in the layers of the sandwich wall structure at the initial time of the analysis $(\tau=0)$ were assumed as constant on each layer according to diagrams shown in Fig 2 b (mean temperature diagrams) and in Fig $2 \mathrm{c}$ (mean humidity diagrams [\%], by weight).

The most important parameters characterising the surroundings air influence on the analysed sandwich structure are the coefficients of the surface film conductance $h$ and resistance of vapour transmission through the composite wall. The relevant values of these parameters were assumed according to Polish Standard PN-ENISO 6946 (1999):

- Coefficient of the surface film on the outside surface $-h_{e}=25,0 \mathrm{~W} /\left(\mathrm{m}^{2} \cdot{ }^{0} \mathrm{~K}\right)$;

- Coefficient of the surface film on the inside surface $-h_{i}=7,7 \mathrm{~W} /\left(\mathrm{m}_{2} \cdot{ }^{0} \mathrm{~K}\right)$;

- Diffusivity resistance of the outside surface of partition $-R_{p e}=13,3 \mathrm{~m}^{2} \cdot \mathrm{h} \cdot \mathrm{Pa} / \mathrm{g}$;

- Diffusivity resistance of the inner surface of partition $-R_{p i}=26,6 \mathrm{~m}^{2} \cdot \mathrm{h} \cdot \mathrm{Pa} / \mathrm{g}$.

For each layer of the considered partition it was necessary to establish appropriate material properties related to the thermal and humidity conditions. The main data used in the computer simulation are given in Table.

To determine thermal conductivity coefficients for the given material, the known linear formula was used

$$
\lambda_{i}=a+b u,
$$

where:

$a, b$ denote constant coefficients; $u$ - the mass of moisture per unit mass of material $[\mathrm{kg} / \mathrm{kg}]$.

To estimate the coefficients $a$ and $b$ a mathematical models presented in Nikitin et al (1999) were used.

The moisture and thermal characteristics for each material in the composite panel are described also by the isotherm of sorption diagrams. Other important material properties are also the coefficient $\delta$ of vapour diffusivity and the coefficient $\beta$ of moisture transmission as the functions of material humidity.

These coefficients depend on different factors. The empirical formulation of such multi-functional relationships for different structural materials is very complex. A few mathematical models have been elaborated. They

Data assumed in computational simulation of the heat transfer and moisture migration

\begin{tabular}{|c|c|c|c|}
\hline Type of layer & $\begin{array}{l}\text { Layer "1" - claddings } \\
\text { (plaster work) }\end{array}$ & $\begin{array}{l}\text { Layer " } 2 \text { " - thermal insulation - } \\
\text { foamed polyurethane }\end{array}$ & $\begin{array}{l}\text { Layer " } 3 \text { " - structural } \\
\text { normal concrete }\end{array}$ \\
\hline $\begin{array}{l}\text { Vapour diffusivity coeffi- } \\
\text { cient } \delta_{p i}\end{array}$ & $\begin{array}{c}\delta_{p 1}=9,20 \cdot 10^{-5} \\
{[\mathrm{~g} /(\mathrm{m} \cdot \mathrm{h} \cdot \mathrm{Pa})]}\end{array}$ & $\begin{array}{c}\delta_{p 2}=38,0 \cdot 10^{-5} \\
{[\mathrm{~g} /(\mathrm{m} \cdot \mathrm{h} \cdot \mathrm{Pa})]}\end{array}$ & $\begin{array}{c}\delta_{p 3}=4,51 \cdot 10^{-5} \\
{[\mathrm{~g} /(\mathrm{m} \cdot \mathrm{h} \cdot \mathrm{Pa})]}\end{array}$ \\
\hline Specific heat of material $c_{i}$ & $c_{1}=0,83\left[\mathrm{~kJ} /\left(\mathrm{kg}^{\circ}{ }^{\circ} \mathrm{K}\right)\right]$ & $c_{2}=1,45\left[\mathrm{~kJ} /\left(\mathrm{kg} \cdot{ }^{\circ} \mathrm{K}\right)\right]$ & $\begin{array}{c}c_{3}=0,83+4.2 u \\
{\left[\mathrm{~kJ} /\left(\mathrm{kg} \cdot{ }^{\circ} \mathrm{K}\right)\right]}\end{array}$ \\
\hline $\begin{array}{l}\text { Thermal conductivity } \\
\text { coefficient } \lambda_{i}\end{array}$ & $\begin{array}{c}\lambda_{1}=0,93+0,8 u \\
{\left[\mathrm{~W} /\left(\mathrm{m} \cdot{ }^{\circ} \mathrm{K}\right)\right]}\end{array}$ & $\begin{array}{c}\lambda_{2}=0,04+0,025 u \\
{\left[\mathrm{~W} /\left(\mathrm{m} \cdot{ }^{\circ} \mathrm{K}\right)\right]}\end{array}$ & $\begin{array}{c}\lambda_{3}=1,454+5,8 u \\
{\left[\mathrm{~W} /\left(\mathrm{m} \cdot{ }^{\circ} \mathrm{K}\right)\right]}\end{array}$ \\
\hline
\end{tabular}


were created by Afonin and Nikitin (2002 and 2003) in order to determine the values of coefficients $\delta_{p}$ and $D_{w}$, assuming numerous mechanisms of moisture transfer. Unfortunately, practical utilisation of such models is very complex, because they need a wide range of input data characterising different properties of considered materials.

For example, to define the value of vapour transmission coefficient $\delta_{p}$, it is necessary to determine the data about the size (mean diameter) of pores, structure of open porosity, volumetric sorptive humidity for the given vapour partial pressure, as indicated by Afonin and Nikitin (2003). On the other hand, the computation of coefficient of moisture transmission $D_{w}$ is possible by taking into account the data concerning the distribution of pore volume in the function of their diameter and thickness of film moistening pores and the angle of capillarity, as proved by Afonin and Nikitin (2002).

For calculation purposes of the considered materials the generalised values of the coefficients $\delta_{p}$ and $D_{w}$ taken from reference books have been used.

In practical design it can be assumed that any building material is characterised by its own coefficient of vapour transmission $\delta_{p}$ which is not dependent on relative air humidity in pores of the material and this assumption was also applied here. According to experimental results presented by Garbalinska (1998), such assumption can be completely adopted for the considered layer of thermal insulation. However, according to Wyrwal (1997) for the layers made of cement mortar or concrete the values of coefficient $\delta_{p}$ significantly differ with changing relative air humidity.

The assessment of moisture transmission coefficient $D_{w}$ influence on the results of numerical simulation is very complex because its influence on the same material can differ in a very wide range.

The schematic graph illustrating the relationships between coefficients of moisture transmission $D_{w}$ and humidity of the material is presented in Fig 3.

The necessary computational data for coefficient $D_{w}$ have been assumed after Fokin (1973).

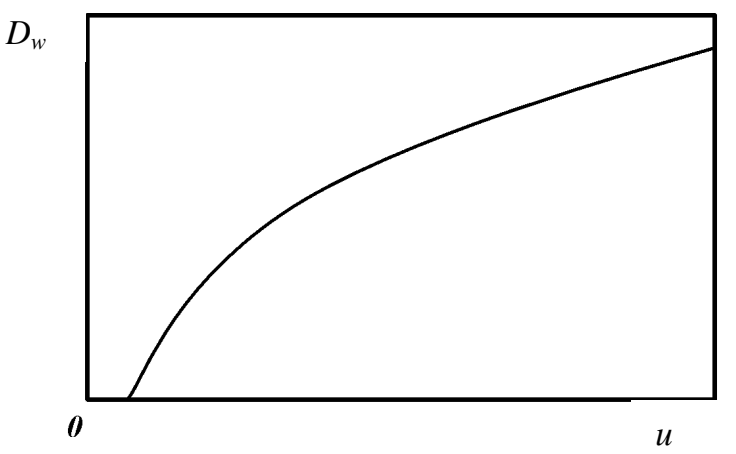

Fig 3. Schematic relationship between moisture transmission coefficient $D_{w}$ and moisture content $u$ in the material

The hypothetical distribution of temperature and humidity across the thickness of the sandwich structure was analysed using the above-mentioned computer program. The respective diagrams shown in Fig 3 were adopted for three different tests prepared for the following simulation data:

- Test 1: for the surface film conductance: $h_{e}=25,0 \mathrm{~W} /\left(\mathrm{m}^{2} \cdot{ }^{0} \mathrm{~K}\right), h_{i}=7,7 \mathrm{~W} /\left(\mathrm{m}^{2} \cdot{ }^{0} \mathrm{~K}\right)$, and for coefficients $\delta_{p 1}, \delta_{p 2}, \delta_{p 3}$ taken from Table 1 and $D_{w 1}, D_{w 2}, D_{w 3}$, after Fokin (1973).

- Test 2: for the surface film conductance: $h_{e}=25,0 \mathrm{~W} /\left(\mathrm{m}^{2} \cdot{ }^{0} \mathrm{~K}\right), h_{i}=7,7 \mathrm{~W} /\left(\mathrm{m}^{2} \cdot{ }^{0} \mathrm{~K}\right)$, for coefficients $\delta_{p 1}, \delta_{p 3}$ and $D_{w 1}, D_{w 2}$, as in Test 1 , for changed values of $\delta_{p 2}$ and $D_{w 3}$ :

$$
\delta_{2}=7,7 \cdot 10^{-5}[\mathrm{~g} /(\mathrm{m} \cdot \mathrm{h} \cdot \mathrm{Pa})], D_{w 3}{ }^{*}=2 D_{w 3} \text {. }
$$

- Test 3: for surface films conductance: $h_{e}=25,0 \mathrm{~W} /\left(\mathrm{m}^{2} \cdot{ }^{0} \mathrm{~K}\right), h_{i}=11,0 \mathrm{~W} /\left(\mathrm{m}^{2} \cdot{ }^{0} \mathrm{~K}\right)$, and for coefficients $\delta_{p 1}, \delta_{p 2}, \delta_{p 3}$ and $D_{w 1}, D_{w 2}, D_{w 3}$ taken as in Test 2.

The exemplary diagrams of temperature and humidity distribution in Fig 4 are presented for the three tests 1-3 given above, carried out for different time intervals: 7 days and 30 days characterising the period of the numerical simulation.

\section{Analysis of some results of numerical simulation}

The diagrams of temperature and humidity presented in Fig 4 plotted in the considered time intervals ( 7 and 30 days from the initial time) show distinctly the relationship between temperature and humidity in the section of the multi-layer partition.

The results of test 1 (curves 1 and 2) show that the correct thermal - humidity condition of materials lasted only 7 days. In that time interval the moisture content in the material did not exceed the maximum permissible values of sorptive humidity. It means that the material remained in the air-dry state, whereas the moisture in pores of materials was transmitted in the form of vapour and surface films. Then, after 7 days the inner layer of partition (concrete layer) began to produce the capillary condensed moisture (reached the saturation point) and thus giving the possibility for moisture migration not only in the form of vapour but also in liquid phase.

The increase of moisture within the inner layer of the partition resulted in significant lowering of its temperature during 30 days. The difference about $10{ }^{\circ} \mathrm{C}$ between temperature of the inside surface of the partition and the indoor room temperature considerably exceeds the permissible limits required by design standards for housing, such as Polish Standard PN-EN-ISO (1999). The interpretation discussed above can be seen in Fig 4 in distribution of curves 3 and 4 (from test 2) obtained for changed values of coefficient $\delta_{p 2}$ and $D_{w 3}$.

It should be emphasised that in real conditions the temperature and humidity distribution for the given time interval could slightly differ from the values obtained theoretically. First of all, this remark refers to diagram 1 (see Fig 4). The main cause for this is that the considered phenomena of heat transfer and moisture transmission depends on many material parameters varying in time and in space of the structure. 

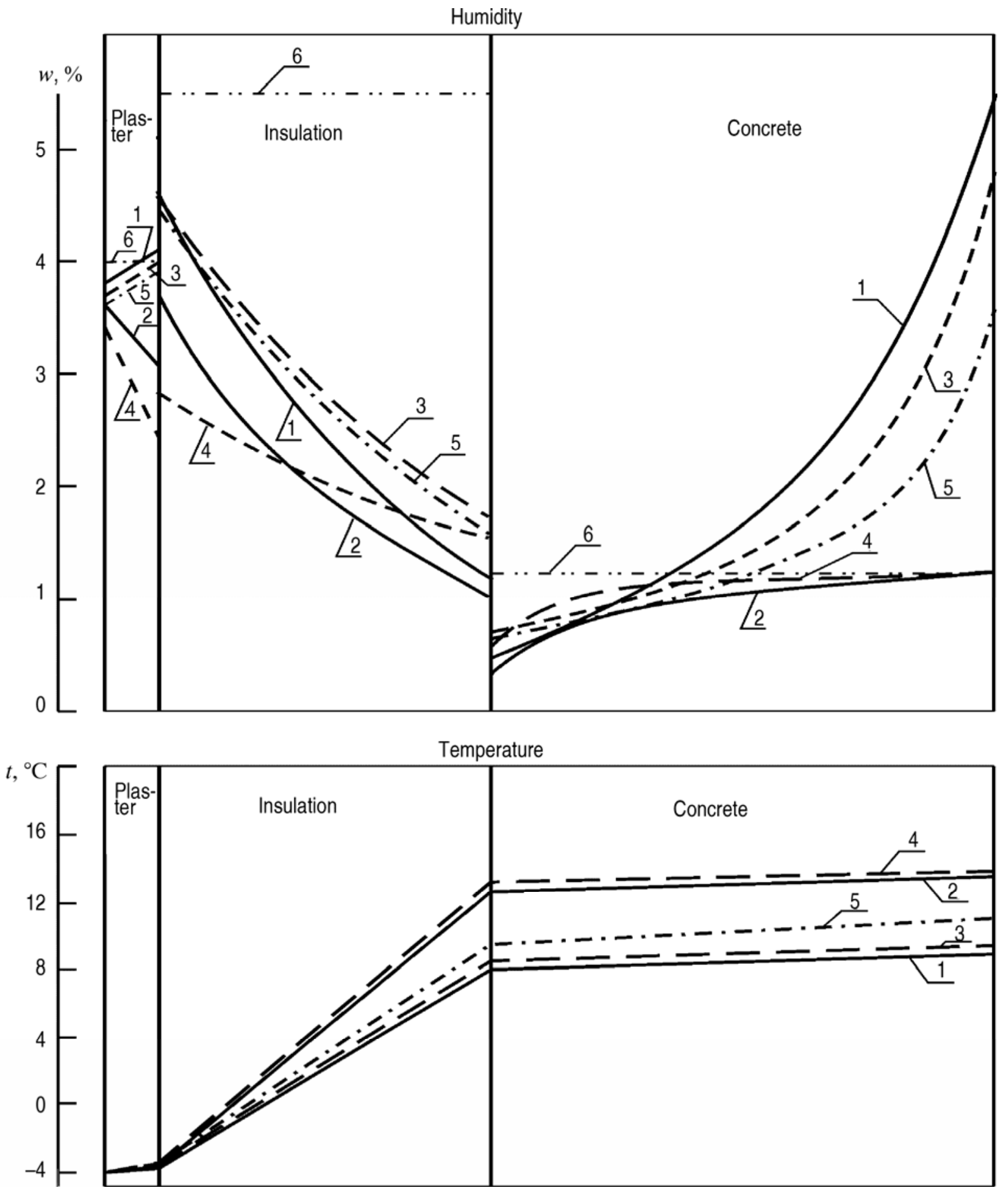

Fig 4. Diagrams showing the humidity and temperature distribution through the multi-layer section of sandwich wall partition: 1 - diagrams from test 1 after 30 days, 2 - diagrams from test 1 after 7 days, 3 - diagrams from test 2 after 30 days, 4 - diagrams from test 2 after 7 days, curves 5 - diagrams from test 3 after 30 days, diagram 6 - maximal sorptive humidity of materials 
The most sensible parameters for such analysis are coefficients $\delta_{p}$ and $D_{w}$ being the characteristic of sorption (de-sorption) curves for building materials, having the significant effects on the values and character of moisture content and on temperature distribution at the thickness of the multi-layer partition.

As shown in Fig 4, a proper estimation of such parameters is extremely important at the stage of design of thermal insulation in a sandwich partition. Unfortunately, for numerous insulating materials available currently on the market there is a lack of data for such important properties. Even for traditionally used insulating building materials the data differ considerably in reference books.

For example, for the considered foamed polyurethane insulation layer, the limit values of vapour diffusivity coefficient $\delta_{p}$ may differ by six. On the other hand, the coefficient of moisture transmission $D_{w}$ strongly depends on the humidity of the material and its value can differ in a wide range, as indicated by Afonin and Nikitin (2002).

The comparison of selected results of numerical simulation for test 1 and test 2 carried out for different values of coefficient $\delta_{p}=38,0 \cdot 10^{-5}$ for test 1 and $\delta_{p}=7,0 \cdot 10^{-5}$ for test 2 has shown that the humidity at the contact surface between the concrete wall and the insulation layer increased twice, whereas the humidity at the inside surface decreased only by $0,26 \%$ (in absolute terms).

Additional numerical tests carried out showed that the increase of insulation layer thickness up to $120 \mathrm{~mm}$ has a positive effect on the thermal-humidity conditions of the considered multi-layer sandwich structure. The humidity of the material in the inner layer after 30 days lowered by $0,56 \%$ (in absolute term), whereas the temperature increased by about $0,7^{\circ} \mathrm{C}$ only.

Other numerical tests proved that the drop of outdoor air humidity from the assumed $95 \%$ to $90 \%$ may result both in lowering the moisture of the outer layer (claddings) on the average by about $0,6 \%$ and in lowering of humidity of the insulation about $0,2 \%$ (in absolute term). However, it had no influence on the humidity condition of the concrete layer, and its temperature field remained constant.

\section{Conclusions}

The computational tests described here have shown the efficiency of the presented numerical program elaborated in order to analyse coupled processes of heat and moisture transmission in sandwich (composite) structures. The problems considered are very complex due to difficulties in giving a precise formulation of thermophysical material parameters describing the processes of heat transfer and moisture migration, eg the coefficient of thermal conductance $\lambda$, the coefficient of vapour diffusivity $\delta_{p}$ and the coefficient of moisture transmission $D_{w}$. These parameters have strong influence on both temperature and humidity fields that appear in sandwich structures such as building partitions.

Precisely predicted values of these coefficients in numerical simulations are recommended taking the re- sults of experimental studies into account. In such analysis proposed here procedures based on analytical formulas of heat and moisture transfer can be used.

To improve the computational accuracy in modelling the thermal engineering problems, it is necessary to assume an exact description of properties characterising the structural capillary-porous materials used in construction of sandwich walls or slabs made of structural concrete or steel building structures.

\section{Acknowledgements}

This paper was elaborated both at the Bialystok Technical University (Poland) and the Brest State University (Belarus) within the frame of Dean Project S/IIB/2/04 with the financial support of bilateral international project.

\section{References}

Bear, J. and Bachmat, Y. (1984) Transport Phenomena in Porous Media. Basic Equations. In: Fundamentals of Transport Phenomena in Porous Media, p. 5-61.

Fokin, K. F. (1973) Thermal Engineering of Building External Partitions. Moscow: Strojizdat, 273 p. (in Russian).

Usowicz, B. (2002) The Universal Model of Mass and Energy Transfer in a Porous Medium. In: Proc of $17^{\text {th }}$ World Congress, USS, Bangkok, Thailand, p. 1-12.

Vozarova, V. (2005) Thermophysical Properties of Granular Food Materials. International Agrophisics, No 19, p. 189192.

Gawin, D. (2000) Modelling of Coupled Higro-Thermal Phenomena in Building Materials and Building Components. Scientific Bulletin, No 853, Lodz Technical University, Poland, 303 p. (in Polish).

Gawin, D. and Lefik, M. (2000) Some Applications of Neutral Networks in Building Physics. Archives of Civil Engineering, 46 (2), p. 255-271.

Kunzel, H. M. and Kiesl, K. (1997) Calculation of Heat and Moisture Transfer in Exposed Building Components. International Journal of Heat Mass Transfer, 40 (1), p. 159-167.

Michieyev, M. A. and Michieyeva, I. (1973) The Basis of Heat Transfer. Moscow: Energia. 320 p. (in Russian).

Lewis, R. W. and Schrefler, B. (1998) The Finite Element Method in the Static and Dynamic Deformation and Consolidation of Porous Media. $2^{\text {nd }}$ Ed John Viley \& Sons. $508 \mathrm{p}$.

Lapko, A.; Nikitin, V.; Prusiel, J. and Kowalczyk, R. (2001) Prediction of Temperature Fields and Thermal Forces in Cylindrical Shell of Silo Chamber. In: Proc of $4^{\text {th }}$ Congress on Thermal Stresses. Osaka, Japan, p. 537-540.

Lapko, A.; Nikitin, V. and Kowalczyk, R. (2002) Numerical Modelling of Heat Transfer and Moisture Migration in Multi - Layer Wall Structures. In: Proc of Structural Engineering World Congress, SEWC 2002, Yokohama, Electronic file T1-3-c4. $8 \mathrm{p}$.

Standard of Design (2004) PN - EN - ISO 6946:2004 Building Components and Building Elements. Thermal Resistance and Thermal Transmittance. Calculation Methods. 27 p. (in Polish).

Nikitin, V.; Guriev, W. and Lapko, A. (1999) Modelling of Processes in Production and Exploitation of Multi-Layer 
Building Structures. Bialystok Technical University, Bialystok. 244 p. (in Polish).

Afonin, A. and Nikitin,V. (2003) Vapour Permeability of Capillary - Porous Materials Taking Into Account Sorption Film and Condensate Flow. In: Proc of International Conference Construction and Architecture. Minsk, Belarus, Febr 3-6, p. 131-139.

Afonin, A. and Nikitin, V. (2002) Calculation of Moisture Transmission Coefficient in Capillary-Porous Building Materials. Journal of Brest Technical University, 1, Brest, p. 10-15 (in Russian).
Garbalinska, H. (1998) Moisture Conditions and Vapour Diffusion Coefficient for Foamed Polystyrene. In: Proc of XLIV National Conference, Krynica, Poland, p. 113-118 (in Polish).

Wyrwal, J. and Swirska, J. (1998) Problems of Moisten of Building Partitions. Studies in Civil Engineering, No 44, Polish Academy of Science, Warsaw. 109 p. (in Polish).

Zienkiewicz, O. C.; Taylor, R. L. and Zhu J. Z. (1991) The Finite Element Method: Its Basis and Fundamentals. $6^{\text {th }}$ Edition, Elsevier; Butterworth-Heinemann. 733 p.

\section{APIE ŠILUMOS IR DRĖGMĖS SKLIDIMO SLUOKSNIUOTŲU巳 SIENŲ IR PLOKŠČIU KONSTRUKCIJOSE MODELIAVIMĄ}

\section{Nikitin, A. Lapko}

Santrauka

Daugelio pastatų sienų ir plokščių konstrukcijos pagamintos iš porètų medžiagų (tokių kaip mūras ar betonas). Šios konstrukcijos yra veikiamos aplinkos poveikių, dèl to jose vyksta nestacionarūs šilumos bei drègmès sklidimo procesai. Šilumos ir drègmès sklidimo daugiasluoksnèse konstrukcijose problema nagrinèta remiantis bendrosiomis Furjè diferencialinèmis lygtimis bei šilumos balanso metodo prielaidomis. Pasiūlytos bendrosios išraiškos, kurios transformuotos i formules, taikomas baigtinių skirtumų metodui. Šiai problemai analizuoti sukurta kompiuterinè programa ir algoritmas, pritaikytas sluoksniuotajai betoninei plokštei su poliuretano izoliacija.

Reikšminiai žodžiai: šilumos perdavimas, drègmės sklidimas, sluoksniuotosios sienos, skaitiniai metodai, analizè, ilgaamžiškumas.

Vadim NIKITIN. Recently working as the professor at the Technical Universities in Bialystok (Poland) in Civil and Environmental Faculty and simultaneously in the Civil Engineering Dept of Brest State University (Belarus). His research interest include mathematical simulation of processes in building construction and technologies, particularly - simulation of higro-thermal phenomena that occur in building structures, as well as statistical methods in experimental analyses.

Andrzej LAPKO. Professor, since many years working at the Bialystok Technical University as the head of the Concrete Structures Department. Member of Civil and Water Engineering Committee of Polish Academy of Science, the Polish delegate of $f i b$ and individual member of IABSE. His research interests reinforced concrete and composite structures, particularly the structures of silos and water tanks, also thermal loads and effects on concrete structures. 